\title{
The Variables that Affect Compliance of Muslim Merchants for Zakat Maal in the District of Cianjur
}

\author{
Dadang Husen Sobana \\ UIN Sunan Gunung Djati Bandung \\ Uus Ahmad Husaeni \\ Universitas Suryakancana \\ Irpan Jamil \\ Universitas Suryakancana \\ Dadang Saepudin \\ Universitas Suryakancana
}

\begin{abstract}
The purpose of this study is to determine the variables that affect the level of compliance among Muslim merchants in the implementation of zakat maal. The quantitative method was used for the investigation and the results were compiled by multiple linear regression analysis. The total population enrolled in this study comprised 100 Muslim merchants. A non-probability sampling technique with this type of sampling was considered suitable for the purpose of this research that the sample collection purpose adapted to the purpose of research. Based on the results of multiple linear regression testing, it can be concluded that compliance zakat maal is affected by the variable level of education, level of income, commitment to Islamic rule, perceptions Zakat justice and transparency of zakat institution.
\end{abstract}

Keywords: Compliance; welfare; Muslim merchants; zakat institution; zakat maal

\section{INTRODUCTION}

Zakat in Islam falls into one of the rules of worship, and the laws of zakat are obligatory for every Muslim. Therefore, problems associated with charity, for example problems regarding collection, management, and distribution of zakat will always be a concern for Muslims. In Islam, there are two types of zakat: zakat maal and zakat fitrah. Zakat maal is imposed on all property owned a muzakki (obligatory charity), whereas zakat fitra is for the self (soul) and is paid by Muslims during Ramadan.

According to Wahab and Rahman (2011), one type of zakat maal is zakat of income. Zakat of income is zakat imposed on acquisitions that includes free salary income and all income. Nurhayati and Nurwasilah (2009) argued that zakat of income using zakat levels are analogous to gold ( 85 grams gold) and is 2.5 percent of the salary or income earned. Zakat of income may also be paid each time earning.

According to Ali (2006), the obligation of zakat in Islam has a fundamental significance. In addition to closely related to aspects of divinity, it is also concerned with economic and social issues. In the aspect of social justice (al'adalah al-ijtima'iyyah), zakat command can be understood as an integrated system that is integral to the achievement of socioeconomic prosperity and social. Herfita and Haroni (2015) concluded that zakat is expected to minimize the income gap between the rich and the poor. In addition, 
the zakat is also expected to increase or help grow the economy, both at the individual level and at the level of social.

Ibrahim (2008) argued that zakat is likely to be an alternative government program as a source of funds to address poverty. While Muchlis and Beik (2013) concluded that zakat is a means of legalized by the Islamic religion in the formation of capital. Capital formation is not solely on the utilization and development of natural resources, but also from the compulsory contributions of the rich. Zakat is also instrumental in improving the quality of human resources and the provision of production facilities and infrastructure.

Zakat not only aids the generation of capital, but also helps overcome the problem of accumulation of wealth in certain circles in the society, which in turn reduces the income gap between groups in society. This notion was supported by Salleh et al (2008), who conducted studies on the effect of zakat on income distribution and found that the charity had a positive effect in reducing the imbalance of income. Beik (2009) found that the zakat program for productive enterprises targeted at mustahik poor, helped reduce poverty by 7.5 percent in Jakarta. Further, the depth and severity of mustahik poverty can also be reduced. As for programs, free hospitalbased zakat can reduce poverty by 10 percent.

Data from the National Board of Zakat (BAZNAS) which refers to the results of the study of the Asian Development Bank (ADB) showed that the potential zakat in Indonesia could reach 100 trillion per year. Recent research from BAZNAS estimated that the national zakat in 2011 would be 217 trillion. Zakat from households amounted to 82.7 trillion, that from the private industry amounted to 114.89, that from BUMN was 2.4 trillion, and that from potential savings was 17 trillion. The amount of zakat may be compiled by BAZNAS of the entire Unit Zakat Management (UPZ) across the entire territory of Indonesia, although steadily increasing yearly, still remains small in number, amounting to 450 billion in 2007 , increasing to 920 billion in 2008 and 1.2 trillion in 2009; then, according to estimates in 2010 amounted to 1.5 trillion. The amount of zakat collected by BAZNAS is approximately 1 percent per year, which is a very small number compared to its potential.

According to BPS Cianjur (2015), the same condition also occurs in the district of Cianjur. Nearly 98 percent of the population in Cianjur is Muslim, with a total population of 2.335 million people. Among these, 182,356 inhabitants work as traders (Muslim merchants). Meanwhile, the poverty rates in Cianjur reached 13.18 percent or 292,219 inhabitants. Although the amount of zakat maal in Cianjur has the potential of reaching 60 billion per year, the value has reached only 4.347 billion per year to date. The participation rate in the Muslim merchants who pay zakat maal is very low considering the total number of Muslim merchants $(182,356)$, i.e., only 8,096 or 4.44 percent of people pay zakat maal regularly. Thus, the annual zakat target of BAZNAS Cianjur in terms of zakat maal remains unfulfilled.

If every Muslim merchant was aware of the obligation to zakat maal and appreciated the various kinds of benefits to be gained by zakat maal, then the potential zakat maal should be achieved. Further, even more important than the funds collected through zakat maal being optimal in amount is that the collected amount be distributed fairly among recipients. This would help to further augment the benefits of zakat. Therefore, the researchers intend to conduct a study to determine the variables that affect the level of compliance in the Muslim merchants pay zakat maal.

\section{LITERATURE REVIEW}

According to Qardawi (1993), in terms of language, the word zakat comes from the root word (masdar) zaka, which means blessing, grow, clean, and well. Al-Zuhayly 
(1995) argued that as for zakat, according to the syara, means the statutory rights (excluded from) a treasure. Zakat refers to a part of certain assets that are required by Allah to be given to poor people. Zakat is called charity for measures that would show the truth (sidq) of a servant in worship and showing obedience to Allah SWT.

In general, zakat is classified into two types, namely zakat soul (nafs) or zakat fitrah and zakat maal. Zakat fitrah is a zakat that works to restore the Muslim man to nature, to purify their soul from impurities (sins) caused by the influence of human relationships and so forth so that it deviates from nature. Zakat maal is imposed on assets owned by a person or institution according to the terms and conditions that have been set (Sari, 2006).

Sartika (2008) concluded that zakat can be used as one form of capital for small business, if zakat management is managed well. Thus, zakat has enormous influence in many ways to the lives of people, among them is the effect on the economy. The other effect of zakat is the equitable sharing of revenue among the Islamic society. While Muhammad and Mas'ud (2005) argued that in other words, the management of zakat in a professional and productive society can contribute to the weak economy and assist the government in improving the economy of the country, namely ummat economic in accordance with its missions. Among the missions are the following:

a) Economic development and business based on the economic and business rules are common and universal;

b) Execution of business ethics and legal procedures;

c) Build economic strength to Islam, so that it becomes a source of funds supporting the propagation of Islam.

Attamimi (2008) concluded that public awareness of the zakat is also closely related to the public understanding. This understanding includes knowledge of the law and the benefits of zakat towards economic justice for Muslims. If the longterm benefits of this zakat can be understood by people, then the level of compliance of the payment may be expected to increase. A person's decision to pay zakat maal is often influenced by his financial condition. Several studies suggest that the financial condition of a person and his family obligations may moderate the relationship of commitment and performance of one's. Most people assume that zakat maal applies only to high-income people, which is the reason for the noncompliance in paying zakat. This assumption causes delays or even reluctance to pay zakat maal. If every Muslim has a high level of compliance to the zakat, the zakat potential should be achieved. Then, the collected zakat can be distributed optimally to the welfare of society.

\section{METHODOLOGY}

This research seeks to investigate compliance to pay zakat maal by using questionnaires sent to participants. The data used in this study are primary data in the form of results of a questionnaire distributed to the Muslim merchants in the district of Cianjur. The number of respondents was 100. According to Wulan and Husaeni (2015) that the nonprobability sampling technique was applied, in particular accidental sampling, which means sampling by coincidence, i.e., anyone who by chance met and elected will be the respondent. Data analysis techniques used in this study is as follows:

\section{Likert Scale}

According to Sudarmanto (2005), RS Likert developed a grading system that represents a bipolar continuum. At the left end are lower grades indicating a negative answer, while at the right end are greater numbers that indicate a positive answer. The Likert format is designed to allow customers responded in varying degrees on each item that describes services or products. The benefit of using the Likert- 
type format over a check list format that only provides "yes" or "no" responses is that the former accounts for the diversity of the responses for an item, ranging from 1 to 5. This allows the consideration of various dimensions of perception and attitude regarding a given issue, allowing respondents to express their opinion about it.

\section{Validity Analysis}

According to Sudjana (2001), validity indicates the level or degree of data being used as evidence to support the conclusions drawn from the value derived from the size or scale used to measure the degree to which something is supposed to be measured. The data is said to be valid when the value corrected item greater than the value of $r$ table with $d f=n-2$.

\section{Reliability Analysis}

According to Sugiono (2008), reliability is defined as the extent of measurement that is free of variance error. To estimate the reliability of the variables studied, we used Cronbach's alpha. The coefficient is generally determined with SPSS software, which is designed to be able to calculate the estimate of reliability. A variable is said to be reliable if the value of Cronbach's alpha is $>0.6$.

\section{Correlation Analysis}

According to Sudjana (2001), correlation analysis is useful to assess the

\section{RESULT AND DISCUSSION}

\section{Validity and Reliability}

The validity and reliability tests were conducted to determine how many questions are valid and reliable, on the basis of a survey of 100 respondents. The results strength, significance, and direction of the relationship between the two variables. The direction of the relationship tested in the correlation analysis can indicate three patterns of relationships. The first pattern is a positive relationship or relationship in a unidirectional pattern; the second pattern is a negative correlation or relationship patterned in the opposite direction; and the last is where there is no pattern in the relationship. In measuring the degree of correlation, Pearson's correlation method was used and the analysis was completed through the SPSS software.

\section{Regression Analysis}

According to Sudarmanto (2005), regression analysis is a type of parametric analysis that can serve as a basis for predicting and analyzing the variants. Some of the objectives of regression analysis, among others, are to determine the regression line equation based on the value of the constants and the resulting regression coefficients, which indicate correlations between independent variables with the dependent variable, and to test the significance of independent variables on the dependent variable through $F$. Regression analysis is used to test for correlations partially between independent variables with the dependent variable and examine the significance of independent variables on the dependent variable through the $t$ test.

of tests on the validity and reliability of the questionnaire items are presented in Table 1. The variables mentioned in Table 1 are the level of education, level of income, commitment to Islamic rule, perception to zakat justice, transparency to zakat institution and Muslim merchants compliance. 
Table 1.

Operationalization of Variables

\begin{tabular}{|c|c|c|c|}
\hline Variable & Items & Correlated Items & Cronbach's Alpha \\
\hline \multirow{6}{*}{ Level of Education } & LE1 & 0.414 & \\
\hline & LE2 & 0.535 & \\
\hline & LE3 & 0.532 & 0.668 \\
\hline & LE4 & 0.544 & \\
\hline & LE5 & 0.528 & \\
\hline & LI1 & 0.595 & \\
\hline \multirow[t]{4}{*}{ Level of Income } & LI2 & 0.657 & 0.738 \\
\hline & LI3 & 0.590 & \\
\hline & LI4 & 0.674 & \\
\hline & CIR1 & 0.410 & \\
\hline \multirow{6}{*}{$\begin{array}{l}\text { Commitment to } \\
\text { Islamic Rule }\end{array}$} & CIR2 & 0.565 & \\
\hline & CIR3 & 0.494 & 0.655 \\
\hline & CIR4 & 0.418 & \\
\hline & CIR5 & 0.585 & \\
\hline & PZJ1 & 0.547 & \\
\hline & PZJ2 & 0.682 & \\
\hline \multirow{5}{*}{$\begin{array}{l}\text { Perception to Zakat } \\
\text { Justice }\end{array}$} & PZJ3 & 0.469 & 0.722 \\
\hline & PZJ4 & 0.639 & \\
\hline & PZJ5 & 0.518 & \\
\hline & PZJ6 & 0.543 & \\
\hline & TZI1 & 0.561 & \\
\hline \multirow{5}{*}{$\begin{array}{l}\text { Transparency to Zakat } \\
\text { Institution }\end{array}$} & TZI2 & 0.571 & \\
\hline & TZI3 & 0.512 & 0.666 \\
\hline & TZI4 & 0.318 & \\
\hline & TZI5 & 0.572 & \\
\hline & MMC1 & 0.564 & \\
\hline \multirow{4}{*}{$\begin{array}{l}\text { Muslim Merchants } \\
\text { Compliance }\end{array}$} & MMC2 & 0.576 & \\
\hline & MMC3 & 0.688 & 0.706 \\
\hline & MMC4 & 0.272 & \\
\hline & MMC5 & 0.689 & \\
\hline
\end{tabular}

Source: Author (2016)

As shown in Table 1, all items pertaining to the considered variables were valid because the value of Cronbach's alpha was positive $(+)$ and greater than $0.1966(\mathrm{r}$ table) with $\mathrm{df}=\mathrm{n}-2$ or $\mathrm{df}=98$. The value of Cronbach's alpha for each variable was greater than 0.6 , ranging from 0.655 to 0.738 , which shows that the four variables were reliable.

\section{Correlation Analysis}

Results of correlation analysis for the variables such as level of education, level of income, commitment to Islamic rule, perception to zakat justice, transparency to zakat institution and Muslim merchants compliance were assessed using Pearson's correlation coefficient. The following are the results of the evaluation of the relationship between the level of education and Muslim merchants compliance.

A close relationship was noted between the level of education and Muslim merchants compliance, and the value of $\mathrm{R}$ was 0.339. This indicated a strong correlation between the variables of the level of education and Muslim merchants compliance. The positive (+) sign of the value indicates that level of education and the Muslim merchants compliance have a unidirectional relationship, indicating that the higher the value of level of education, the higher the value of Muslims merchants compliance. The model summary of the level of education and Muslim merchants compliance is described in Table 2. 
Table 2.

Model Summary of the Level of Education and Muslim

Merchants Compliance

\begin{tabular}{ccccc}
\hline Model & $\mathrm{R}$ & R Square & $\begin{array}{c}\text { Adjusted R } \\
\text { Square }\end{array}$ & $\begin{array}{c}\text { Std. Error of the } \\
\text { Estimate }\end{array}$ \\
\hline 1 & $.339^{\mathrm{a}}$ & .115 & .106 & 1.912 \\
\hline
\end{tabular}

Source: Author (2016)

A close relationship was also noted between the level of income and Muslim merchants compliance, with the value of $\mathrm{R}$ being 0.661 . This indicates that there was a strong enough correlation between the variables of the level of income and Muslim merchants compliance. Since the value of $\mathrm{R}$ is positive (+), indicating that the level of income and Muslim merchants compliance have a unidirectional relationship, meaning that the higher the value of level of income, the higher the value of Muslim merchants compliance. This result is showed in Table 3.

Table 3.

Model Summary of the Level of Income and Muslim

Merchants Compliance

\begin{tabular}{ccccc}
\hline Model & $\mathrm{R}$ & R Square & $\begin{array}{c}\text { Adjusted R } \\
\text { Square }\end{array}$ & $\begin{array}{c}\text { Std. Error of the } \\
\text { Estimate }\end{array}$ \\
\hline 1 & $.661^{\mathrm{a}}$ & .436 & .431 & 1.526
\end{tabular}

Source: Author (2016)

A close relationship was noted between commitment to Islamic rule and Muslims merchant compliance, with the value of $\mathrm{R}$ being 0.510 ; this indicates a strong correlation between the variables of the commitment to Islamic rule and Muslim merchants compliance. The positive $(+)$ value of $R$ indicates that commitment to
Islamic rule and the Muslim merchants compliance have a unidirectional relationship, which implies that the higher the value of commitment to Islamic rule, the higher the value of Muslim merchants compliance. This result is illustrated in Table 4.

Table 4.

Model Summary of the Commitment to Islamic Rule and Muslim Merchants Compliance

\begin{tabular}{ccccc}
\hline Model & $\mathrm{R}$ & R Square & $\begin{array}{c}\text { Adjusted R } \\
\text { Square }\end{array}$ & $\begin{array}{c}\text { Std. Error of the } \\
\text { Estimate }\end{array}$ \\
\hline 1 & $.510^{\mathrm{a}}$ & .260 & .252 & 1.749
\end{tabular}

Source: Author (2016)

A close relationship was noted between perception to zakat justice and Muslim merchants compliance, with the value of $\mathrm{R}$ being 0.640 ; this indicates a strong correlation between the variables of the perception to zakat justice and Muslim merchants compliance. The positive (+) value of $\mathrm{R}$ indicates that perception to zakat justice and the Muslim merchants compliance have a unidirectional relationship, which implies that the higher the value of perception to zakat justice, the higher the value of Muslim merchants compliance. The result of this relationship is presented in Table 5. 
Table 5.

Model Summary of the Perception to Zakat Justice and Muslim Merchants Compliance

\begin{tabular}{ccccc}
\hline Model & $\mathrm{R}$ & $\mathrm{R}$ Square & $\begin{array}{c}\text { Adjusted R } \\
\text { Square }\end{array}$ & $\begin{array}{c}\text { Std. Error of the } \\
\text { Estimate }\end{array}$ \\
\hline 1 & $.640^{\mathrm{a}}$ & .410 & .404 & 1.562
\end{tabular}

Source: Author (2016)

A close relationship was noted between transparency to zakat institution and Muslim merchants compliance, with the value of $\mathrm{R}$ being 0.859 ; this indicated a strong correlation between the variables of the transparency to zakat institution and Muslims merchant compliance. The positive sign (+) of the value indicates that transparency to the zakat institution and the Muslim merchants compliance have a unidirectional relationship, implying that the higher the value of transparency to zakat institution, the higher is the value of Muslim merchant compliance. This result is showed in Table 6.

Table. 6

Model Summary of the Transparency to Zakat Institution and Muslim Merchants Compliance

\begin{tabular}{ccccc}
\hline Model & $\mathrm{R}$ & R Square & $\begin{array}{c}\text { Adjusted R } \\
\text { Square }\end{array}$ & $\begin{array}{c}\text { Std. Error of the } \\
\text { Estimate }\end{array}$ \\
\hline 1 & $.859^{\mathrm{a}}$ & .738 & .735 & 1.041 \\
\hline
\end{tabular}

Source: Author (2016)

3. Regression Analysis

Correlation analysis of all five independent variables on the dependent variable was followed by regression analysis to determine the influence of independent variables on the dependent variable. The results of the regression analysis are expressed as the following regression equation:

$$
\begin{gathered}
Y=0.514-0.270 X_{1}+0.040 X_{2} \\
+0.221 X_{3}+0.118 X_{4} \\
+0.841 X_{5}+e
\end{gathered}
$$

The coefficients are presented in Table 7.

\begin{tabular}{|c|c|c|c|c|c|c|}
\hline \multirow[t]{2}{*}{ Model } & & \multicolumn{2}{|c|}{ Unstandardized Coefficients } & \multirow{2}{*}{$\begin{array}{c}\begin{array}{c}\text { Standardized } \\
\text { Coefficients }\end{array} \\
\text { Beta }\end{array}$} & \multirow[t]{2}{*}{$\mathrm{t}$} & \multirow[t]{2}{*}{ Sig. } \\
\hline & & B & Std. Error & & & \\
\hline \multirow{6}{*}{1} & (Constant) & .514 & 1.334 & & .386 & .701 \\
\hline & $\mathrm{x} 1$ & -.270 & .085 & -.237 & -3.173 & .002 \\
\hline & $\mathrm{x} 2$ & .040 & .177 & .036 & .224 & .823 \\
\hline & $\mathrm{x} 3$ & .221 & .065 & .195 & 3.424 & .001 \\
\hline & $\mathrm{x} 4$ & .118 & .113 & .140 & 1.038 & .302 \\
\hline & $\times 5$ & .841 & .109 & .774 & 7.688 & .000 \\
\hline
\end{tabular}

Table 7.

Coefficients

In multiple regression analysis, a significant influence simultaneously or together was noted between the dependent variables and independent variables. This is 
evidenced by the results of the F test, which had a significance level of 0.000 , a value that was lower than $\alpha=0.05$. This is also supported by the results of the analysis of determination coefficient that is showed in Table 8, which indicated that the independent variables in this study were related to zakat compliance among Muslim merchants in 79.6 percent of the cases, while variables other than those included in this study accounted for the remaining 20.4 percent.

Table 8.

\begin{tabular}{ccccc}
\multicolumn{4}{c}{ Model Summary of Multiple Regression Analysis } \\
\hline Model & $\mathrm{R}$ & R Square & $\begin{array}{c}\text { Adjusted R } \\
\text { Square }\end{array}$ & $\begin{array}{c}\text { Std. Error of the } \\
\text { Estimate }\end{array}$ \\
\hline 1 & $.892^{\mathrm{a}}$ & .796 & .785 & .937
\end{tabular}

Source: Author (2016)

\section{CONCLUSION}

From the results of this study, we concluded some importants points. First, the correlation analysis revealed that all independent variables (level of education, level of income, commitment to Islamic rule, perception to zakat justice, transparency to zakat institution) have a strong enough relationship to dependent variable (Muslim merchants compliance). Whereas the correlation of the variable transparency in the zakat institution with the variable compliance among Muslim merchants was 0.859 .

Second, the multiple regression analysis revealed a significant influence simultaneously or together between the independent variables and dependent variables included in this study, amounting to 79.6 percent, while the remaining 20.4 percent can be affected by other variables not included in this study.

In the light of these results, the researchers want to provide the following inputs towards the BAZNAS in Cianjur district: (1) improve knowledge in the field of technology and management, since this may increase the degree of professionalism among zakat administrators in the management of zakat funds, as well as the actualization of information systems and transparency regarding distribution of zakat funds to the society, (2) BAZNAS should increase their level of cooperation with
DKM (Prosperity Council of Mosques), leaders of society, and the chaplain to absorb funds from the public zakat maal, (3) to improve the understanding of zakat, BAZNAS, government, and the Islamic scholars should take more intensive steps towards imparting religious education and creating a social awareness regarding zakat, (4) the zakat system may be optimized by a pick-up service and an online payment system, to facilitate the payment of zakat by muzakki.

\section{ACKNOWLEDGEMENTS}

The first author wishes to thank State Islamic University of Sunan Gunung Djati Bandung for supporting in this research. The second author wishes to thank LPDP, Graduate School State Islamic University of Syarif Hidayatullah Jakarta, and the Faculty of Economic and Business Suryakancana University for supporting this research. The third and fourth authors wish to thank Faculty of Economic and Business Suryakancana University for moral supporting in this research. 


\section{REFERENCES}

Al-Zuhayly, Wahbah. 1995. Zakat, Kajian Berbagai Mazhab. Bandung: Remaja Rosdakarya.

Ali, Nuruddin Muhammad. 2006. Zakat sebagai Instrumen dalam Kebijakan Fiskal. Jakarta: Raja Grafindo Persada.

Badan Pusat Statistik Kabupaten Cianjur. Kabupaten Cianjur dalam Angka Tahun 2015.

Faisal Attamimi. 2008. Persepsi Masyarakat Muslim tentang Zakat di Kota Palu. Jurnal Hunafa 5 (3): 377-390.

Gamsir Bachmid, Ubud Salim, Armanu \& Djumahir. 2012. Perilaku Muzakki dalam Membayar Zakat Mal (Studi Fenomenologi Pengalaman Muzakki di Kota Kendari). Jurnal Aplikasi Manajemen 10 (2): 426.

Herfita \& Haroni. 2015. Analisis Tingkat Kesadaran Masyarakat Kecamatan Medan baru dalam Membayar Zakat. Jurnal Ekonomi da Keuangan 3 (7): 490-491.

Ibrahim, P. 2008. Pembangunan Ekonomi Melalui Agihan Zakat: Tinjauan Empirikal. Jurnal Syariah 16: 223244.

Irfan Syauqi Beik. 2009. The Use of Zakat as Financing Source for Micro and Small Scale Enterprises and Its Role in Reducing Poverty: a case Study in Jakarta, Indonesia. Unpublished PhD Dissertation, IIUM Malaysia.

Muchlis, Ahmad \& Syauqi Beik, Irfan. 2013. Analysis of Factors Affecting Compliance Level of Paying Zakat: A Case Study in Bogor Regency. Jurnal al-Muzara'ah 1 (1): 84.

Muhammad dan Ridwan Mas'ud. 2005. Zakat dan Kemiskinan Instrumen Pemberdayaan Ekonomi Umat. Yogyakarta: UII Press.

Nurhayati, Sri, \& Nurwasilah. 2009. Akuntansi Syariah di Indonesia. Jakarta: Salemba Empat.
Qardawi, Yusuf. 1993. Hukum Zakat. Bogor: Pustaka Litera Antar Nusa.

Sari, Elsi Kartika. 2006. Pengantar Hukum Zakat dan Wakaf. Jakarta: Grasindo.

Sartika, Mila. 2008. Pengaruh Pendayagunaan Zakat Produktif terhadap Pemberdayaan Mustahiq pada LAZ Yayasan Solo Peduli Surakarta. Jurnal Ekonomi Islam La-Riba II (1): 76-90.

Sudarmanto, R.G. 2005. Analisis Regresi Linier Berganda dengan SPSS. Yogyakarta: Graha Ilmu.

Sudjana. 2001. Metode Statistika. Bandung: Tarsito.

Sugiyono. 2008. Metode Penelitian Bisnis (Pendekatan Kuantitatif, Kualitatif, dan R \& D). Bandung: Alfbeta.

Wahab, Norazlia, \& Rahman. 2011. A Framework to Analyze the Efficiency and Governance of Zakat Institution. Journal of Islamic Accounting and Business Research (2): 43-63.

Wulan, Elis, Ratna \& Husaeni, Uus Ahmad. 2015. Analysis of the Variables that Affect Bookstore Customer Satisfaction. International Journal of Nusantara Islam 03 (2): 27-36.

Dadang Husen Sobana

Islamic Banking Management

Faculty of Sharia and Law

State Islamic University of Sunan Gunung Djati

Bandung

Indonesia

dadanghusen_bandung@yahoo.co.id

Uus Ahmad Husaeni

Islamic Economic

Faculty of Islamic Economic and Business

Suryakancana University

Cianjur

Indonesia

uusahmad1@gmail.com 
Irpan Jamil

Islamic Economic

Faculty of Islamic Economic and Business

Suryakancana University

Cianjur

Indonesia

irpanjamil76@gmail.com
Dadang Saepudin

Islamic Economic

Faculty of Islamic Economic and Business

Suryakancana University

Cianjur

Indonesia

dadangsaepudin57@gmail.com 